\title{
Latin America and the Cop21 Agreement: A Most Severe
}

\section{Implementation Problematic}

\author{
Jan-Erik Lane ${ }^{1 *}$ \\ ${ }^{1}$ Fellow with Public Policy Institute, Belgrade; 10 Charles Humbert, 1205 Geneva; 559A, 3rd Floor, \\ Thuya Street, 9th Quarter, Yangon, Myanmar \\ *Jan-Erik Lane, E-mail: janeklane@gmail.com
}

Received: January 21, 2017 Accepted: January 28, $2017 \quad$ Online Published: February 16, 2017

doi:10.22158/jepf.v3n1p107 URL: http://dx.doi.org/10.22158/jepf.v3n1p107

\begin{abstract}
As the Latin American countries have hardly started developing implementation strategies of the agreed upon COP21 objectives, their situation should be more researched. The CO2:s are really high in 2 countries but medium in all the others; Mexico and Brazil that face enormous difficulties with global warming. Thus, the dominant energy reliance remains much fixed upon oil and natural gas, but with some third component like hydro, geothermal or biomass power. Hydro power is used much but it presents a risk as it requires lots of water, which further global warming may deny-look at Venezuela today. Brazil's plans for 30 new dams in the Amazons together with ongoing logging and new agriculture will destroy the rain forest period Major investments in wind, solar, geo-thermal power or/and nuclear power are called for, besides the plenty biomass and hydro power. But to make a great energy transformation towards renewables and atomic power, the Latin American countries need massive assistance from the promised Super Fund. Only Uruguay has come far with the changes towards renewables, producing electricity with $100 \%$ renewables, including wind power.
\end{abstract}

\section{Keywords}

COP21, decarbonisation, Latin American countries, fossil fuel dependency, hydro power, implementation strategies, sustainable economy, Stern, Sachs

\section{Introduction}

Latin America does not figure prominently in the global debate about CO2 emissions. This civilization only has two countries with huge emissions, namely Brazil and Mexico. In terms of CO2:s per capita, Argentina and Chile come high on the global ranking. Tiny Trinidad-Tobago ranks almost highest in the world on emission/capita. However, the CO2:s in the various countries are large enough to be counted in the implementation of Cop21. The overall environmental degradation in several Latin American countries has been much researched and debated: the Amazons, the Titicaca Lake and the 
Caribbean for instance. Yet, also the governments of Latin American countries have bound themselves to respect the COP21 process. It includes the following goal targets:

- Halting C02 emissions by 2018,

- Reduce CO2 emissions from 2020,

- Achieve CO2:s reduction by $40 \%$ in 2030 ,

- Eliminate fossil fuels as energy sources by second half of 21 rst century.

In this paper I will discuss whether these objectives are implementable by the governments of LA nations: Mexico, Venezuela, Columbia, Brazil, Peru, Bolivia, Chile, Uruguay, Paraguay and Argentina. My argument is that it will depend upon their country specific energy mix whether such an enormous reduction in emissions is feasible or not (Ramesh, 2015; Conca, 2015).

\section{GDP-CO2 Links in Latin America}

In 2015, Latin America had a population of around 626 million. In 2014, Latin America had a combined nominal GDP of 55,734 million USD and a GDP PPP of 7,532 million USD, which makes it a medium affluent continent or civilisation. In 2030, the population of Latin America will reach 705 million, an increase of 17\% from 2012. Despite falling birth rates and the rapid growth of the 65+age group in 2012-2030, the region has now and in 2030 an overwhelmingly young age profile in 2030. Almost $60 \%$ of the population will be aged 40 years and under with a median age of just 34.3 years.

Latin American countries are classified as either emerging economies or Third World countries. Most economies in Meso and South America experienced their take-off rather early in the 20th century (Rustow, 1960), but they all failed to catch-up with mature Western economies due to the seminal decline in the late 20th century, after the depression. Recently, Latin American countries pursue the catch-up strategy (Barro, 1991, 1993, 1995), but not with same success as the Asian miracles.

In any case, Latin American nation will need more energy to respond to the challenges of the $21 \mathrm{st}$ century: poverty, unemployment, youth bulk and last but not the least emissions and environmental degradation.

It is true that Latin America has experienced a period of economic development for two decades now, resulting in considerable rates of economic growth. These countries have benefited differently from this process, linked with the turn to democracy. But in any case, we may expect to find growing emissions of greenhouse gases, similar to what has been found on the global level and in Asian countries, for example. Let me pin down what is involved in this GDP + CO2 expansion.

\subsection{Total Emission 1990}

First, we examine the evidence about total CO2 emissions in 1990 and emissions per capita for 1990 as well. Figure 1 ranks these countries above according to total GDP and total CO2:s in 1990. 


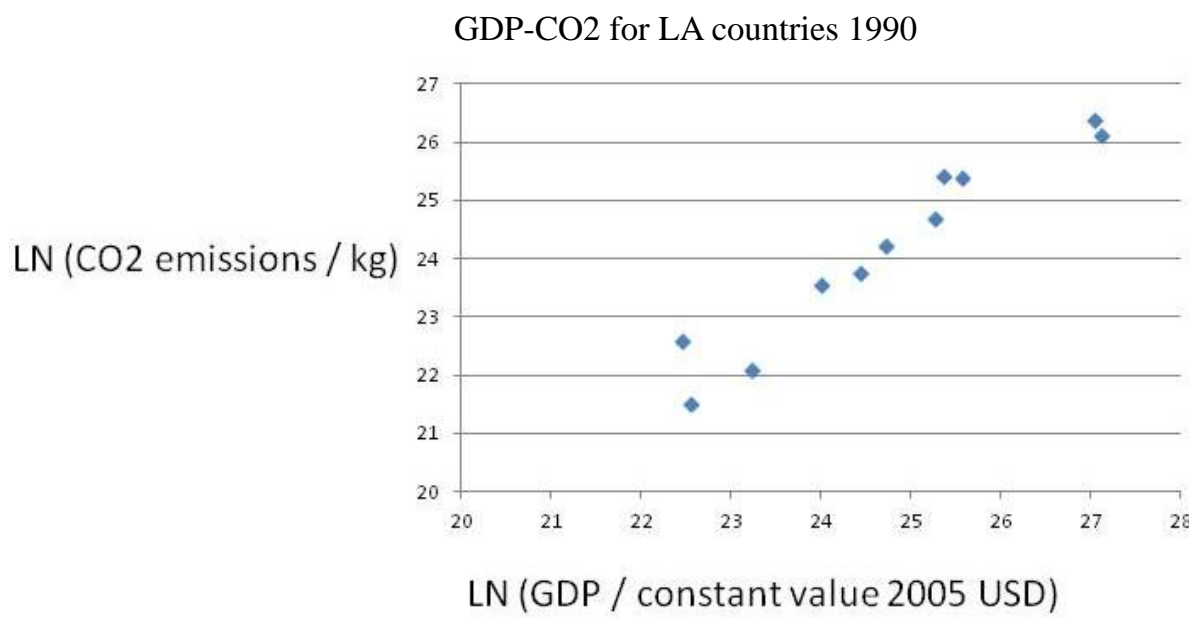

Figure 1. GDP and CO2 1990: $y=0,99 x ; R^{2}=0,93$

The countries with lowest total emissions of $\mathrm{CO} 2$ were: Paraguay, Uruguay and Bolivia, while the largest emitters included: Mexico, Brazil and Venezuela. In terms of total $\mathrm{CO} 2$ emissions, the variation between countries stem from their level of economic development. The only exception is Paraguay, where emissions are higher than Bolivia, although the former is more poor than the latter. Most emissions are to be found in the two economic giants, Brazil and Mexico.

\subsection{0: Emission/Capita}

Let us look at the 1990 emissions per capita in Figure 2. The pictures is different from that of total emissions, as population size matters.

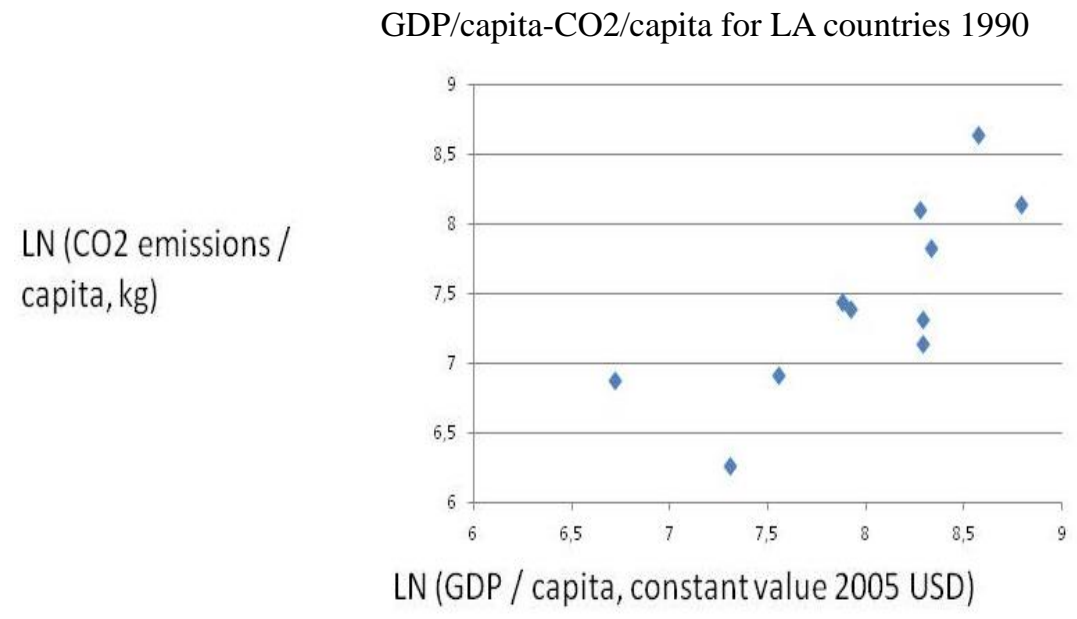

Figure 2. GDP/Capita-Emissions/Capita: $y=0,88 x, R^{2}=0,61$

The per capita emissions of $\mathrm{CO} 2$ goes up with GDP per capita, but not in a linear fashion. The lowest emissions/capite were to be found in Paraguay, Bolivia and Peru, whereas the highest per capita emissions were to be found in Venezuela, Mexico and Argentina. 


\subsection{Total Emissions 2014}

In 2014, after 24 of economic development, Latin American coutries have moved up considerably on the GDP scale, reflecting economic advances, especially in some of these countries. However, the missions of $\mathrm{CO} 2$ have also moved to the right in Figure 3.

GDP-CO2 for LA countries 2014

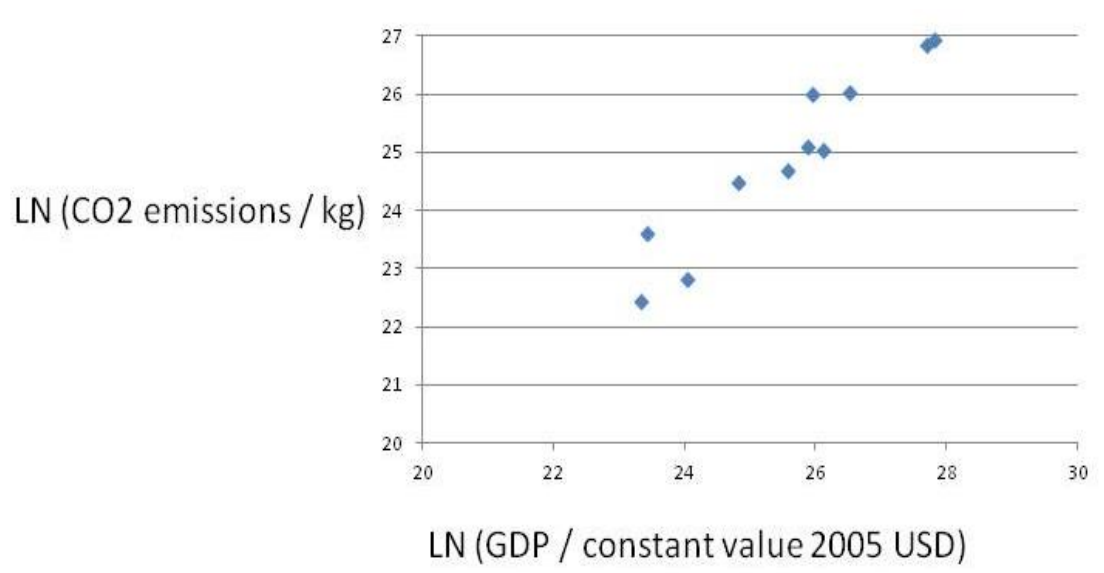

Figure 3. GDP-COP in Latin America 2014: $y=0,9403 x, R^{2}=0,9136$

The countries with the lowest total emissions of $\mathrm{CO} 2$ were: Paraguay, Uruguay and Bolivia, while the largest emitters included Brazil, Mexico and Argentina. We have to look especially at Uruguay, scoring surprisingly low with a fairly advanced economy. It may be intersting also to look at the emissions per capita today.

\subsection{Emissions/Capita 2014}

One must always remember that total $\mathrm{CO} 2$ :s and $\mathrm{CO} 2$ :s per capita are very different things.

GDP/capita-CO2/capita for LA countries 2014

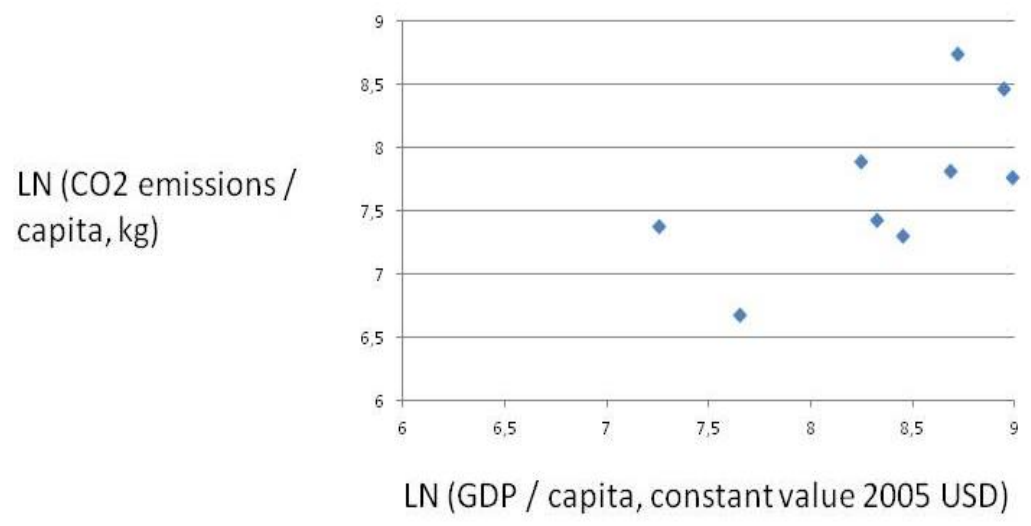

Figure 4. 2014: Emissions/Capita: $y=0,73 x, R^{2}=0,53$ 
The countries with the lowest total emissions of $\mathrm{CO} 2$ were Paraguay, Colombia and Bolivia, while the largest emitters included Venezuela, Argentina and Chile.

\section{Energy and $\mathrm{CO} 2$}

The major finding so far is that $\mathrm{CO} 2$ :s, whether in total or per capita, increases over time with the growth in GDP. The focus in the COP21 framework is upon anthropogenic emissions, stemming mainly from the consumption of energy in a wide sense. Generally, the two major sources of CO2:s are fossil fuels in electricity production and petroleum in transportation sector.

\subsection{Implementation}

With COP21, energy and emissions policy-making becomes a question for international governance. It is supposed to go on for decades, involving country evaluation and soft control. Yet, the COP21 approach is a decentralised one, combined with international oversight, and the creation of a global warming fund with millions for support to poor countries and emerging economies (Stern, 2007). Thus,each government will struggle with the endemic implementation problems, as analysed in the theory of policy implementation. Complete and successful implementation of policies is a figment of the imagination, we learnt by major scholars like Pressman, Wildavsky and Sabatier.

\subsection{Global Kaya Model}

The basic theoretical effort to model the greenhouse gases, especially $\mathrm{CO} 2 \mathrm{~s}$, in terms of a so-called identity is the deterministic Kaya equation. The Kaya identity, "I = PAT"-model type, describes environmental (I)mpact against the (P)opulation, (A)ffluence and (T)echnology (Kaya \& Yokoburi, 1997).

In theories of climate change, the focus is upon so-called anthropogenic causes of global warming through the release of Greenhouse Gases (GHG). To halt the growth of the GHG:s, of which CO2:s make up about 70 per cent, one must theorize the increase in CO2:s over time (longitudinally) and its variation among countries (cross-sectionally). As a matter of fact, $\mathrm{CO} 2$ :s have very strong mundane conditions in human needs and social system prerequisites. Besides the breading of living species, like Homo sapiens for instance, energy consumption plays a major role. As energy is the capacity to do work, it is absolutely vital for the economy in a wide sense, covering both the official and the unofficial sides of the economic system of a country. The best model of carbon emissions to this day is the so-called Kaya model. It reads as follows in its standard equation version-Kaya's identity:

Kaya's identity projects future carbon emissions on changes in Population (in billions), economic activity as GDP per capita (in thousands of \$US(1990)/person year), energy intensity in Watt years/dollar, and carbon intensity of energy as $\mathrm{Gton} \mathrm{C}$ as $\mathrm{CO}_{2}$ per TeraWatt year" (http://www.climatemodels.uchicago.edu/kaya/kaya.doc.html).

Concerning the equation, it may seem premature to speak of a law or identity that explains carbon emissions completely, as if the Kaya identity is a deterministic natural law. It will not explain all the variation, as there is bound to be other factors that impact, at least to some extent. Thus, it is more 
proper to formulate it as a stochastic law-like proposition, where coefficients will be estimate using various data sets, without any assumption about stable universal parameters. Thus, we have this equation format for the Kaya probabilistic law-like proposition, as follows: $Y=a+b_{1} X_{1}+b_{2} X_{2}+b_{3} X_{3}$ $+\ldots+b_{t} X_{t}+u$

Note: $\mathrm{Y}=$ the variable that you are trying to predict (dependent variable); $\mathrm{X}=$ the variable that you are using to predict $\mathrm{Y}$ (independent variable); $\mathrm{a}=$ the intercept; $\mathrm{b}=$ the slope; $\mathrm{u}=$ the regression residual. http://www.investopedia.com/terms/r/regression.asp\#ixzz4Mg4Eyugw

Thus, using the Kaya model for empirical research on global warming, the following anthropogenic conditions would affect positively carbon emissions: The close link in the Kaya model may be visualized in Figure 5.

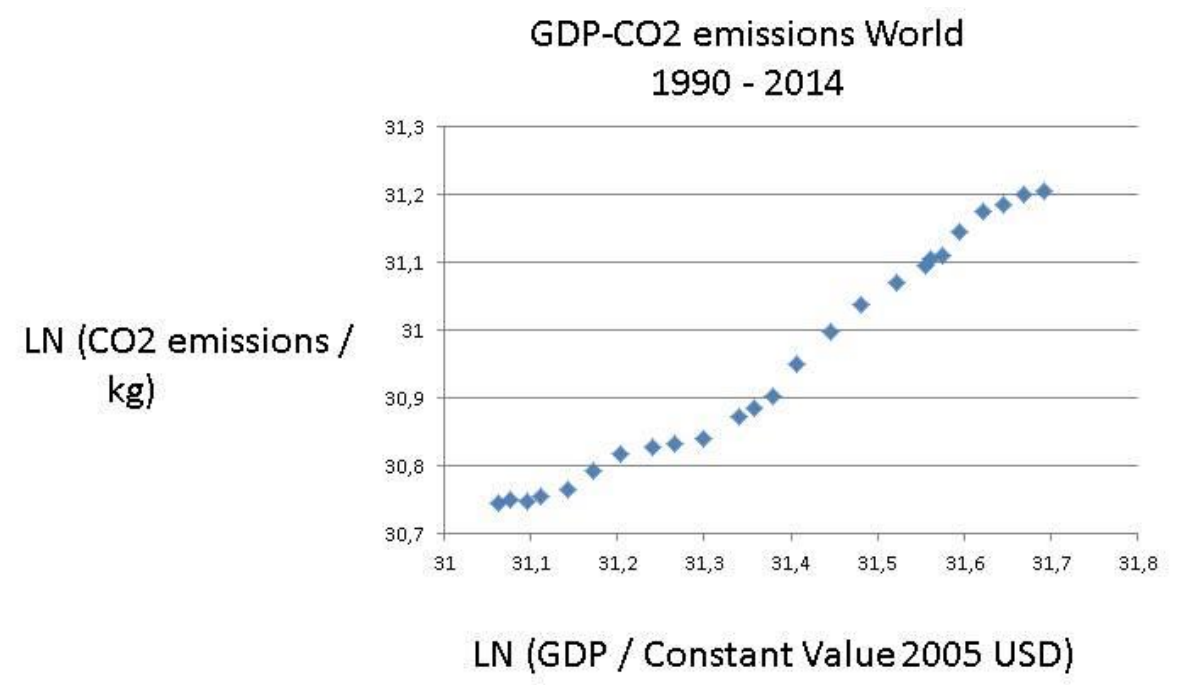

Figure 5. Global GDP-CO2 Link: $y=0,80 x+5,96 ; R^{2}=0,97(N=59)$

The Kaya model findings show that total GHG:s go with larger total GDP. To make the dilemma of energy versus emissions even worse, we show in Figure 2 that GDP increase with the augmentation of energy per capita.

\subsection{Latin America 2015}

How things stand now appear from Table 1, which presents the key data for major Latin American countries in 2015. CO2:s are increasingly both in totals and per capita, which implies that these nations must start policy-making in order to comply with the COP21 goals. 
Table 1. Overview of CO2:s 1990-2015 in Latin America

\begin{tabular}{lllllll}
\hline & CO2 1990 & CO2 2015 & Co2/Cap 1990 & Co2/Cap 2015 & CO2/GDP 1990 & CO2/GDP 2015 \\
& (Kton) & (Kton) & $($ Ton $)$ & $($ Ton $)$ & $(\mathrm{Kg} / 1000$ ) & $(\mathrm{Kg} / 1000$ ) \\
\hline Argentina & $109.017,90$ & $191.198,80$ & 3,33 & 4,40 & 526,21 & 355,10 \\
Brazil & $220.388,40$ & $486.229,10$ & 1,47 & 2,34 & 143,03 & 161,84 \\
Chile & $33.294,07$ & $81.110,21$ & 2,53 & 4,52 & 274,07 & 204,07 \\
Colombia & $52.613,00$ & $80.967,00$ & 1,54 & 1,68 & 204 & 129 \\
Ecuador & $16.554,93$ & $41.749,43$ & 1,62 & 2,59 & 216,83 & 241,29 \\
Mexico & $289.946,30$ & $472.017,80$ & 3,39 & 3,72 & 269,92 & 225,20 \\
Paraguay & $2.160,60$ & $5.553,11$ & 0,51 & 0,84 & 84,94 & 96,77 \\
Peru & $20.722,86$ & $52.572,17$ & 0,95 & 1,68 & 180,27 & 143,55 \\
Uruguay & $3.906,93$ & $7.394,97$ & 1,26 & 2,15 & 127,66 & 108,01 \\
Venezuela & $110.642,60$ & $178.568,10$ & 5,57 & 5,74 & 385,49 & 367,90 \\
\hline
\end{tabular}

Source: EDGARv4.3.2, European Commission, Joint Research Center (JRC)/PBL Netherlands Environmental Assessment Agency. Emission Database for Global Atmospheric Research (EDGAR), release version 4.3.2. http://www.edgar.jrc.ec.europe.eu

Olivier, J. G. J., Janssens-Maenhout, G., Muntean, M., \& Peters, J. A. H. W. (2016). Trends in global CO2 emissions: 2016 Report. European Commission, Joint Research Center (JRC), Directorate C-Energy, Transport and Climate; PBL Netherlands Environmental Assessment Agency, The Hague.

The overall predicament in Latin America appears clearly in Table 1: sharp increase in total $\mathrm{CO} 2$ emissions as well as in emissions per capita in all countries, big differences in emissions between the countries reflecting size of economy, and a weak trend towards smaller emissions per GDP unit. We now proceed to examine a few countries in detail in order to pin down the variation in policy conditions for the promoting of the COP21 goals above. The emissions per capita follows the GDP per capita differences between the LA nations, with Argentina and Chile in the top and Bolivia and Paraguay in the bottom.

\section{Fossil Fuels}

In LA, fossil fuels play a major role in energy consumption, but it is not coal. Oil and natural gas dominate.

\subsection{Argentina}

Although this country has had a volatile walk economically, it keeps expanding its $\mathrm{CO} 2$ emissions as a function of GDP. Figure 6 shows a smoth linear growth trend between GDP and CO2:s for the last 24 years, except for the years of the economic collapse. 
GDP - CO2 for Argentina $1990-2014$

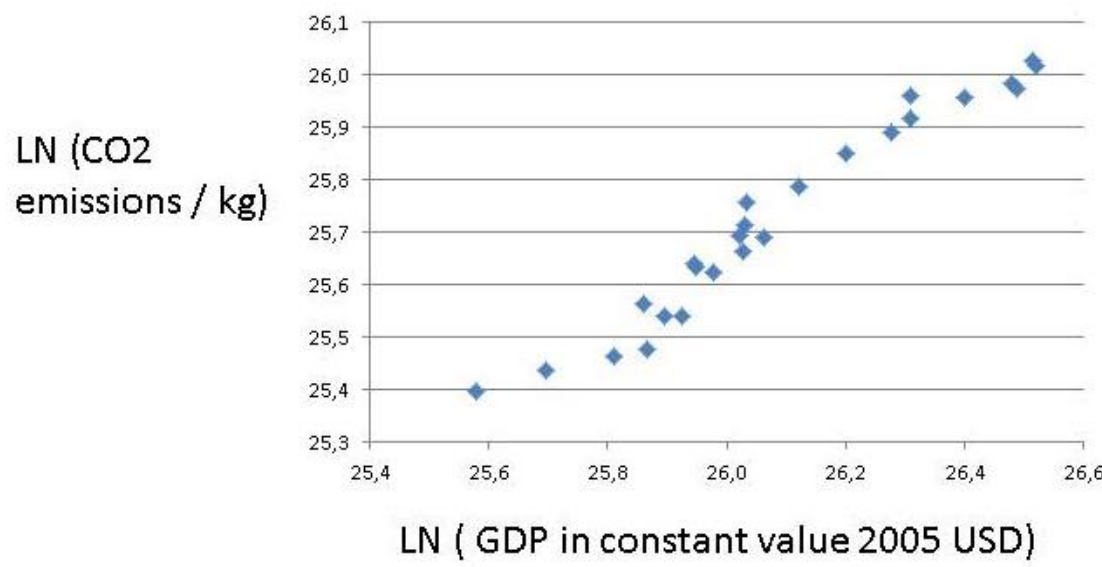

Figure 6. GDP-CO2: $y=0,7409 x ; R^{2}=0,96$

Now, what is the energy mix behind this increase in $\mathrm{CO} 2$ :s that is quite substantial? Figure 7 has the answer.

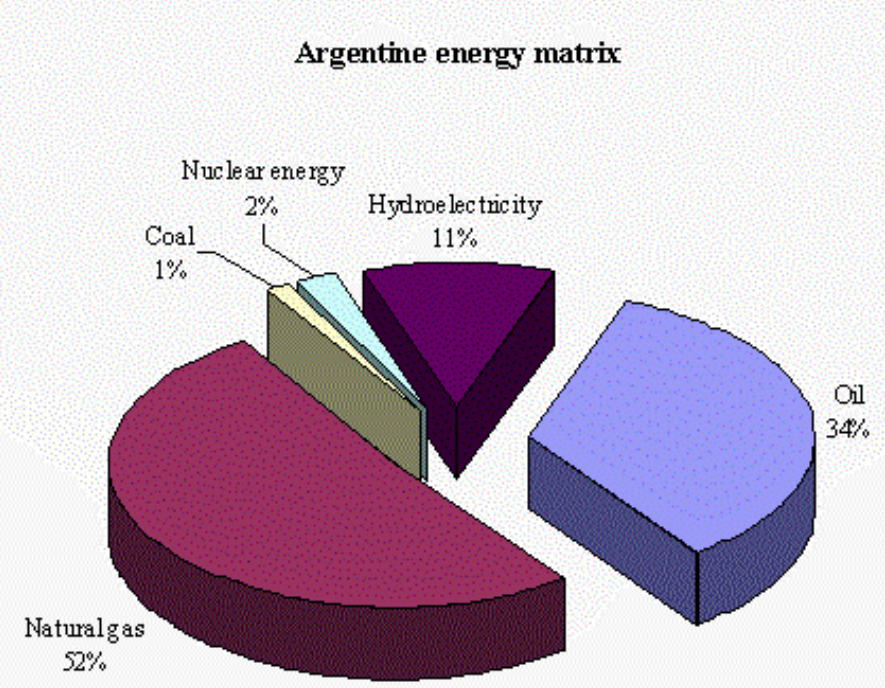

Figure 7. Energy Consumption in Argentina

Source: BP Statistical Review of World Press (information corresponding to 2011).

Argentina depends to more than $85 \%$ on fossil fuels, but it is not coal that figures prominently in this energy mix but natural gas and oil. This reminds of Qatar and Iran. Natural gas is better for halting global warming than coal, on the condition that it does not leak out before burning. But there is bound to occur leakages.

Argentina disposes of hydro power, but the snow over the Andes is diminishing just as the glaciers are 
melting fast. The country needs to turn to solar power or nuclear power in order to accomplish the promised $40 \%$ reduction with COP 21.

\subsection{Mexico}

One would expect to find huge $\mathrm{CO} 2$ emissions in this large emerging economy with lots of oil production. Countries like the Gulf States have massive $\mathrm{CO} 2$ :s because they drill and refine oil and natural gas. For Mexico holds the following situation (Figure 8).

GDP - CO2 for Mexico $1990-2014$

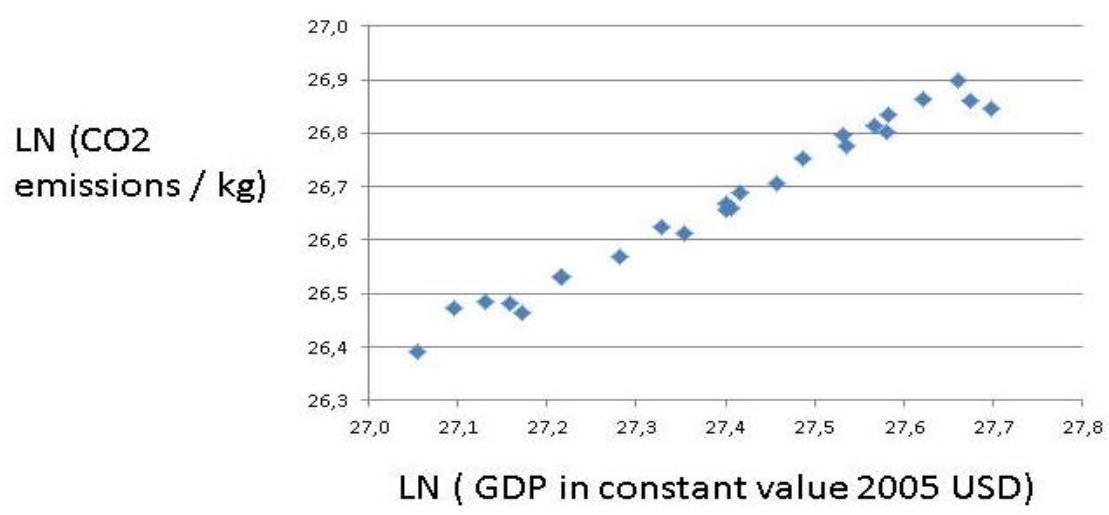

Figure 8. GDP-CO2 in Mexico: $y=0,77 x ; R^{2}=0,98$

The close link between economic development and $\mathrm{CO} 2$ is discernible in the data, but the emissions growth seems to stagnate in the last years. This is of course a promising sign, whether it is the start of a COP21 inspired 40\% reduction in CO2:s remains to be seen. I doubt so, but let us enquire into the energy mix of this huge country that is of enormous economic importance to both North and South America (Figure 9).

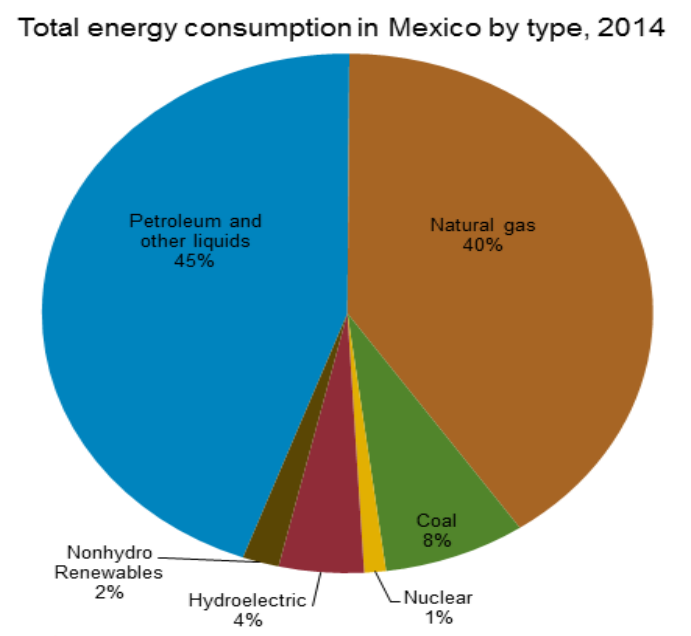

eia Source: U.S. Energy Information Administration, BP Statistical Review

Figure 9. Energy Mix for Mexico 
Few countries are so deependent upon fossil fuels as Mexico. One find the same patter with some of the Gulf States. The Mexican government must start now to reduce this dependency, by for instance eliminating coal and bringing down petreoleum, instead betting upon solar, wind and nuclear power. Mexico will face severe difficulties with the $40 \%$ reduction target in COP21. It has a fast growing population with many in poverty and an expanding industry sucking electricity. Can economic growth and decarbonisation go together here?

Mexico employs fossil fuels for rapid economic development. Actually, the country had its take-off stage decades ago (Rustow, 1960). But eonomic development has been volatile often. Now Mexico is an emerging economy with a clear catch-up strategy (Barr, 1991, 1993, 1995). But its link between GDP and energy, portrayed in Figure 10 is too dependent upon oil and gas. Why not solar energy?

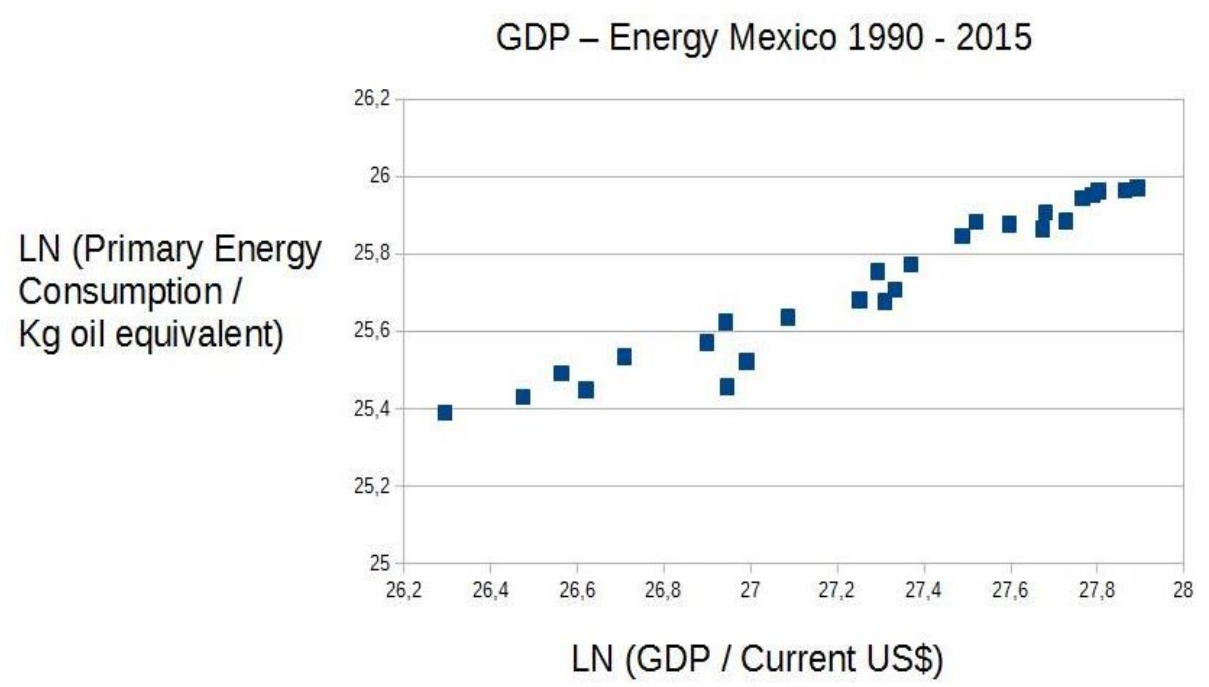

Figure 10. Mexico's GDP-Energy Link: $y=0.399 x ; R 2=0.945$

It is true that Mexico has started many solar power plants, more than, e.g., Argentina, but will the country also close than plants for fossil fuels?

\subsection{Chile}

Chile has the most advanced economy in Latin America, and it has very $\mathrm{CO} 2$ emissions per capita, as expected. Yet, Figure 11 indicates that Chile has managed to halt its yearly increases of CO2:s. 
GDP - CO2 for Chile $1990-2014$

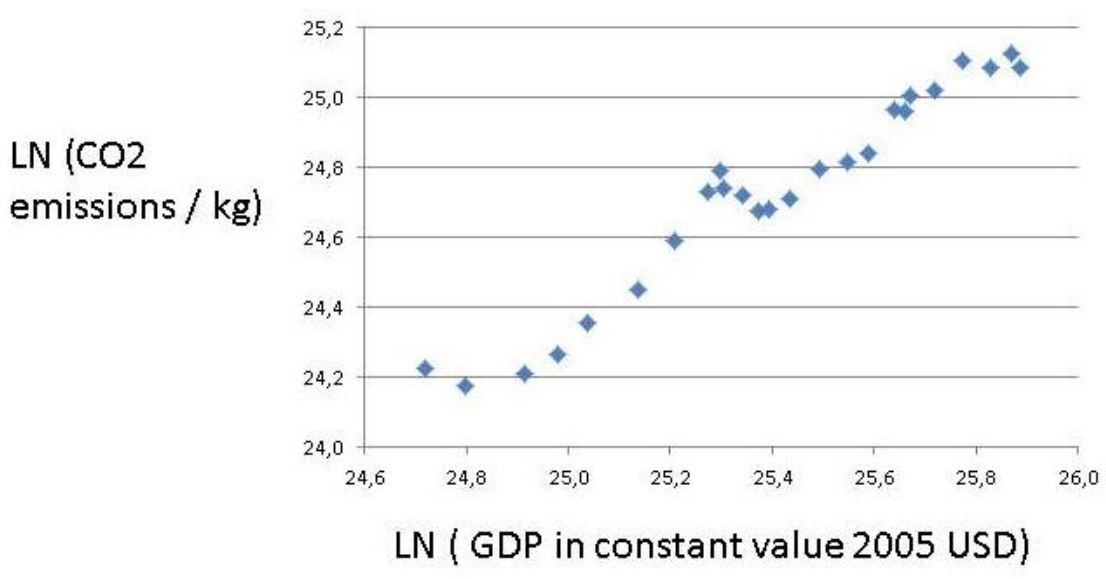

Figure 11. GDP-CO2 in Chile: $y=0,88 x ; R^{2}=0,95$

One should emphasize that $\mathrm{CO} 2$ emissions are big in this country with an advanced economy and lots of mining. And theyhave followed the rate of economic growth for a number of years, just to stall recently. One reason for the halting of these emissions is the successful turn to massive solar power in the large mining fields in the North, at high altitudes in the Andes with plenty of sun. Yet, Chile b needs fossil fuels—-see Figure 12.

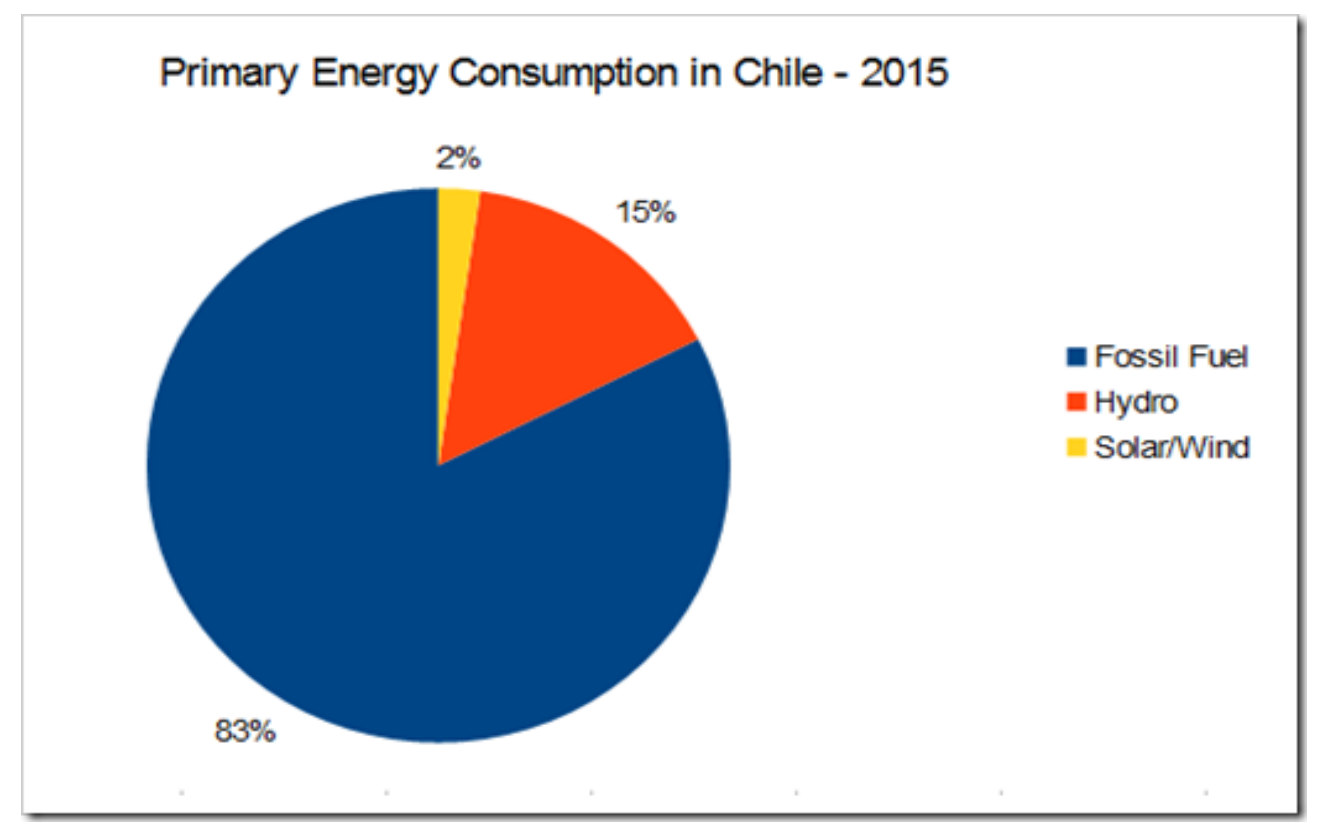

Figure 12. Energy Consumption in Chile

Although Chile has diversified considerably towards renewables and nuclear power, it still relies to more than $80 \%$ upon fossil fuels, coal, natural gas and petroleum. However, it possesses the technology for augmenting the share of renewables and atomic power. And hydro power is essential for Chile, 
which is also true of Colombia, Ecuador and Honduras.

\subsection{Ecuador}

This poor country relies to some 75 per cent upon oil. It has hydro power, as expected, but the fossil fuel dependency is as great as $80 \%$ (Figure 13). Importing this petroleum must be costly.

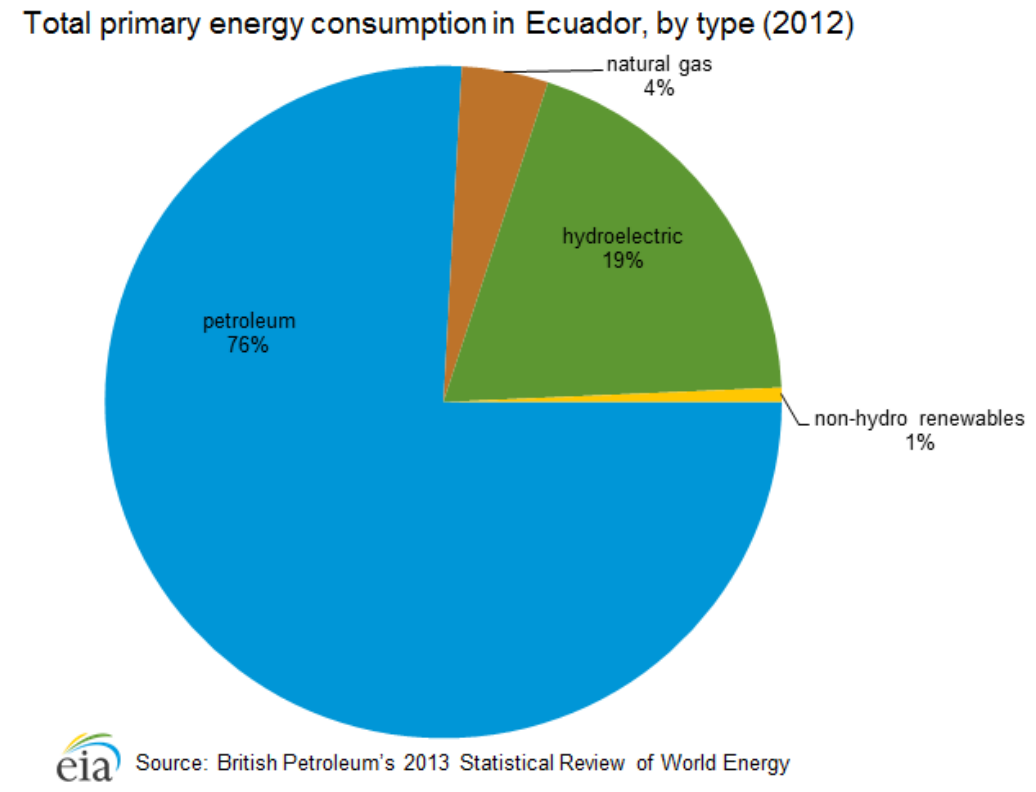

Figure 13. Energy Mix in Ecuador

We note hydro power in many LA countries. The most reliant upon water and its fall power capacity is the giant Brazil.

\section{Hydro Power}

As several of the Latin American countries dispose of multiple rivers, they rely much upon hydro power-a clear renewable source of energy. IN many cases, the rivers are linked to the Andes or the Amazons, as with Peru. Thus, exploiting hydro power poses severe environmental challenges.

\subsection{Brazil}

Brazil has for a long time been in the forefront of environmental concerns. On the one hand, it has paved the way for an alternative to the oil dominance in transportation by developing a domestic biomass industry on large scale. The ethanol is derived from immense sugar plantations and it has reduced oil dependency, especially when international petrol prices have skyrocketed. On the other, there is the constant worry that Brazilian governments are ineffective in protecting the lungs of the Planet Earth, the giant rain forest in the Amazons.

First, we may establish that Brazil produces much $\mathrm{CO} 2 \mathrm{~s}$, and this as a function its economic development (Figure 14). 
GDP - CO2 for Brazil $1990-2014$

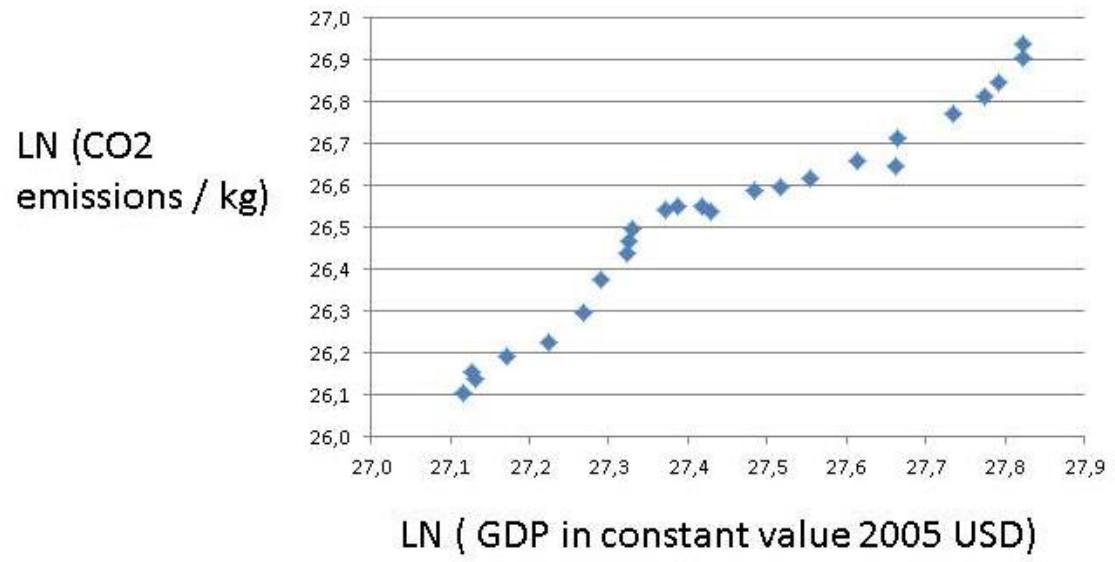

Figure 14. GDP-CO2 in Brazil: $y=1,02 x ; R^{2}=0,95$

The trend in Brazil for CO2:s is like in Argentina up and up. When the burning of the rain forest is added, then Brazil is one of the largest $\mathrm{CO} 2$ emitter in the world. The country may reply that its energy mix and its huge forests decrease $\mathrm{CO} 2$ :s by consuming carbon (Figure 15).

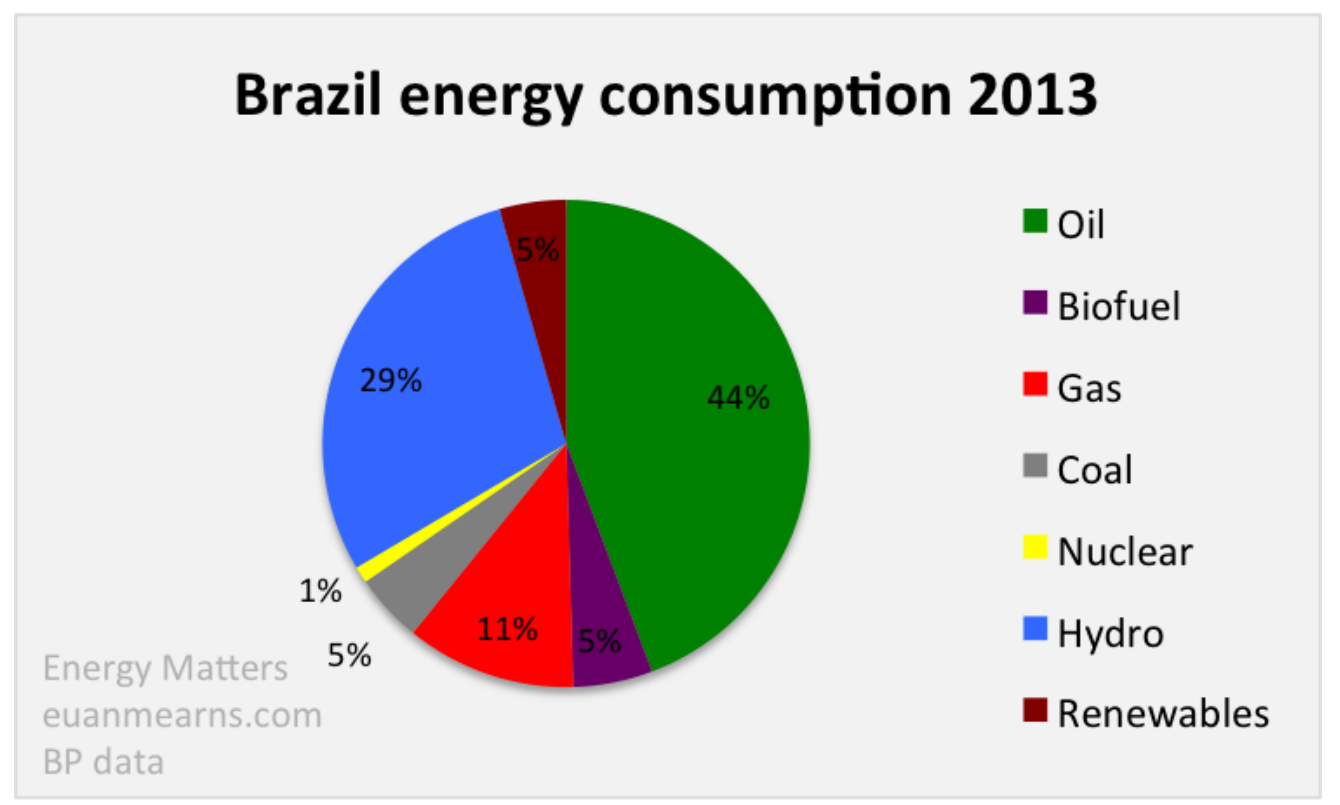

Figure 15. Energy Mix of Brazil

Source: http://www.euanmearns.com/brazil-samba-energy/

Hydroelectric power is massive in Brazil and capacity has grown steadily since 1965 . However, hydro production has been down owing to late and light rains. Brazil is one of the few countries in the world where liquid bio-fuel production is significant: ethanol. Gas production in Brazil is significant, but Brazil has very little of coal production. In 2006, the discovery of vast oil resources in the sub-salt 
strata of the Santos Basin promised petroleum bonanza, but deep water and sub-salt setting has posed technical challenges and high costs. Brazil has 3 nuclear reactors, but nuclear provides $1 \%$ of primary energy.

One can hardly say that it will easy for Brazil to live up to its COP21 commitments, despite its comparatively low dependence upon fossil fuels. Its large hydro power supply is vulnerable to droughts, as rivers dry up. And then one must add the political difficulties in managing the oil and gas reserves properly in giant enterprise Petrobas. The huge Mato Grosso could be used for renewable energy generation, wind and solar power.

Brazil's plan of building some 30 dams in the Amazons is completely at odds with global ambitions behind the UNFCCC and the COP21 project. It would give the country massive amounts of energy for a short time span, some of which could be exported with profit. In the long run, the policy is self-defeating, as it would increase $\mathrm{CO} 2$ emissions and could stumble on water shortages. Dams require lots of cement that give $\mathrm{CO} 2$ :s. And the land over spilling water kills the rain forest just like logging and agriculture.

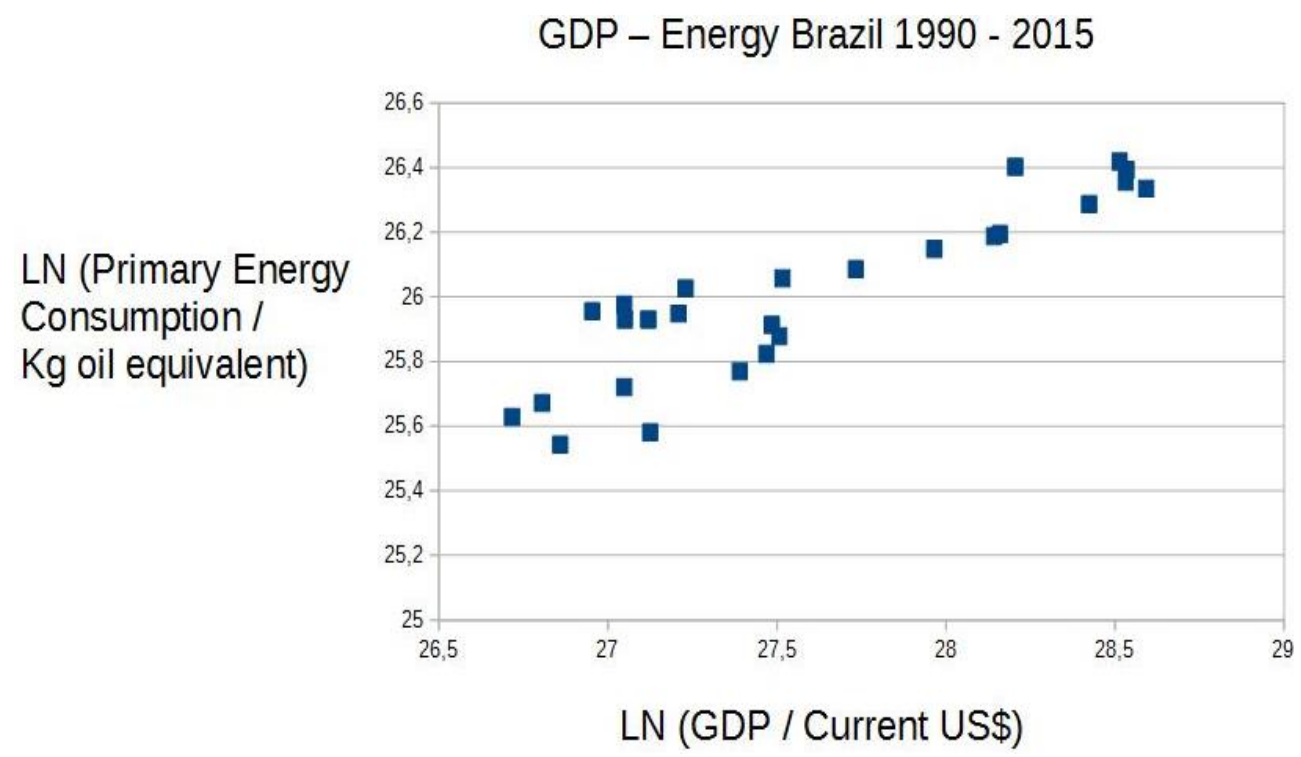

Figure 16. Brazil: GDP+Energy: $y=0.386 x ; R 2=0.81$

One may speculate about the policy reason for Brazil's plan to go for much more hydro power. The country already exports electricity. Figure 16 shows the close link between economic development and energy in Brazil.

The majority of the political elite may believe that transforming the Amazons will secure future high GDP growth, but it is an erroneous belief, neglecting the environmental effects that may be very costly. If water levels go down in the many rivers in the Amazons delta, then the cement barrages are worthless. 


\subsection{Venezuela}

Energy is an interesting aspect of this nation, which is now in great turmoil because of the lack of it, despite the immense oil and gas resources of this country. Just as with otheroil producing countries, one expects the $\mathrm{CO} 2$ :s to be quite substantial. Figure 17 confirms thiss expectation, but one may note many yearly ups and downs in reWhy this link is not a smooth one may be explained both by the energy mix and the volatile politics of Venezuela.

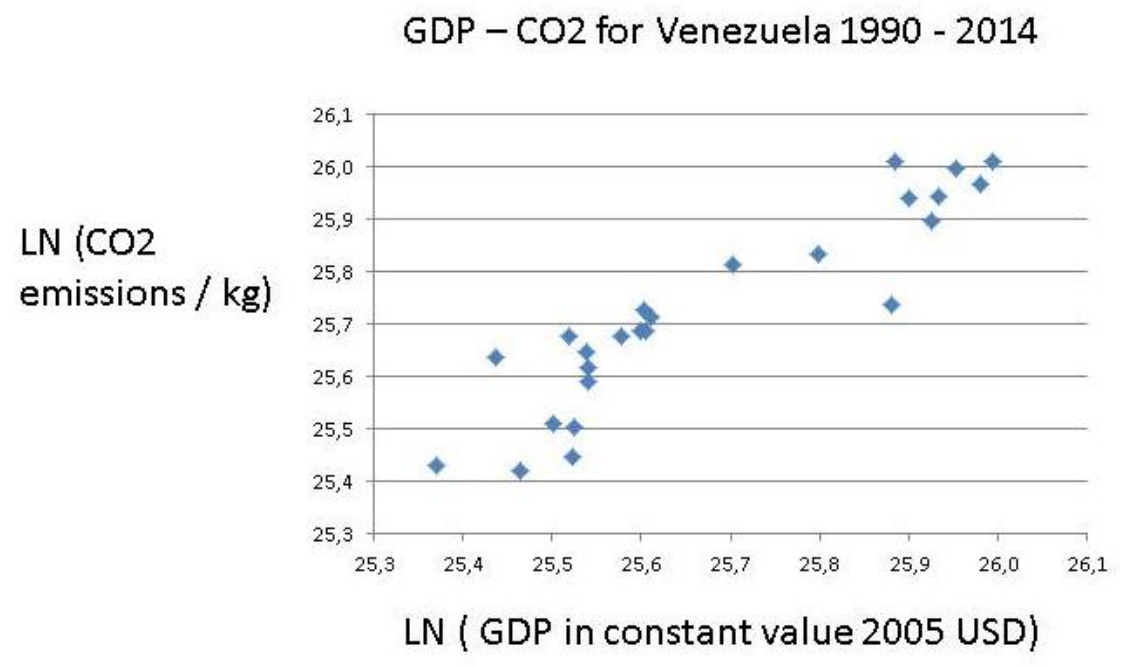

Figure 17. GDP-CO2: $y=0,8739 x ; R^{2}=0,8473$

\section{Total energy consumption Venezuela, by type (2010)}

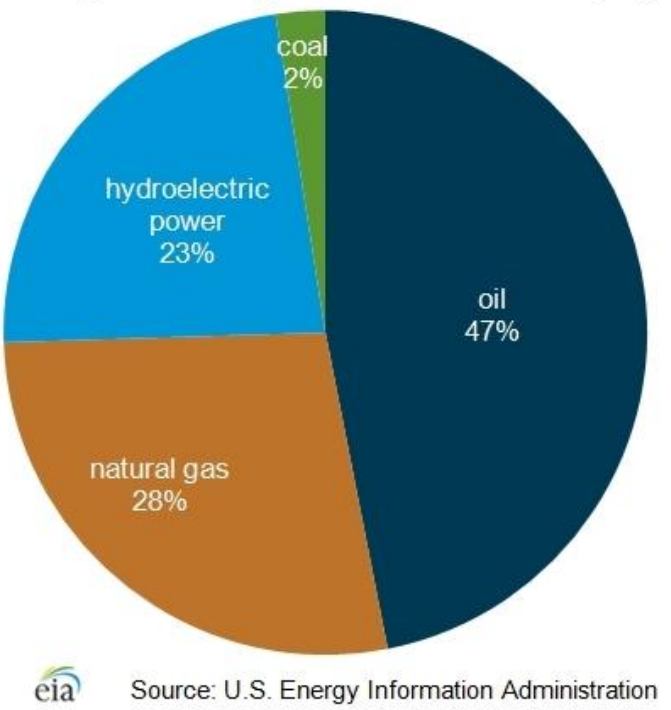

Figure 18. Venezuela's Energy Mix

The dependency upon fossil fuels is high in Venezuela, but the country differens from Mexico in that it disposes of considerable hydro power. Typical of Latin America is that several countries make use of 
hydro power to mitigate their dependency upon fossil fuels, mainly oil and natural gas. In the case of Venezuela, it is the water resources that have failed, causing such electricity chaos, resulting in loss of output and work. Strangely, the Venezuelan government has not taken any steps towards precaution, building back up generators based upon its massive oil and gas reserves. Perhaps the hope of a totally carbon free society is an illusion: What happens when water dries up for instance?

\subsection{Uruguay}

This rather wealthy country is very interesting, as it has conducted a consistent energy policy, favouring renewables (Figure 19).

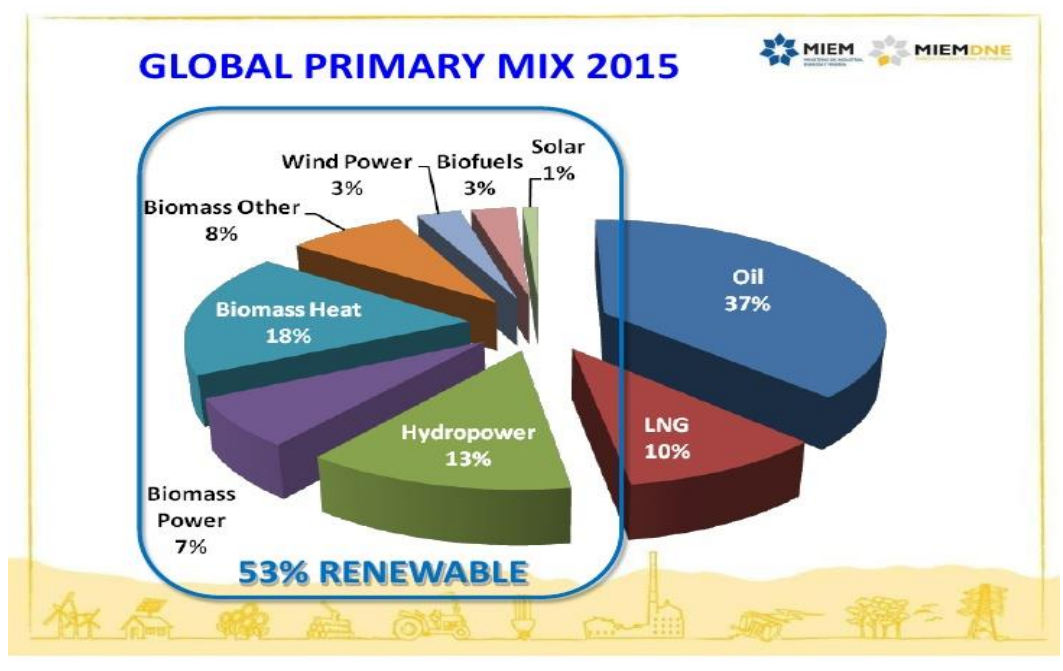

Figure 19. Uruguay

Source: http://www.slideshare.net/dailye/uruguay-galain

Uruguay with a more 50\% share of renewable energy today can no doubt succeed with complying with COP21 and its $40 \%$ decrease target. But it needs more energy transformation towards solar and wind power. Actually, it uses quite much bio-energy, which sadly pollutes with $\mathrm{CO} 2$.

\subsection{Paraguay}

Here we have a different energy profile, reflecting the poverty of this country. In Paraguay, wood coal almost dominates, which is a negative. It pollutes a lot, directly for human beings and indirectly for mankind. In addition, it is conducive to deforestation (Figure 20). 


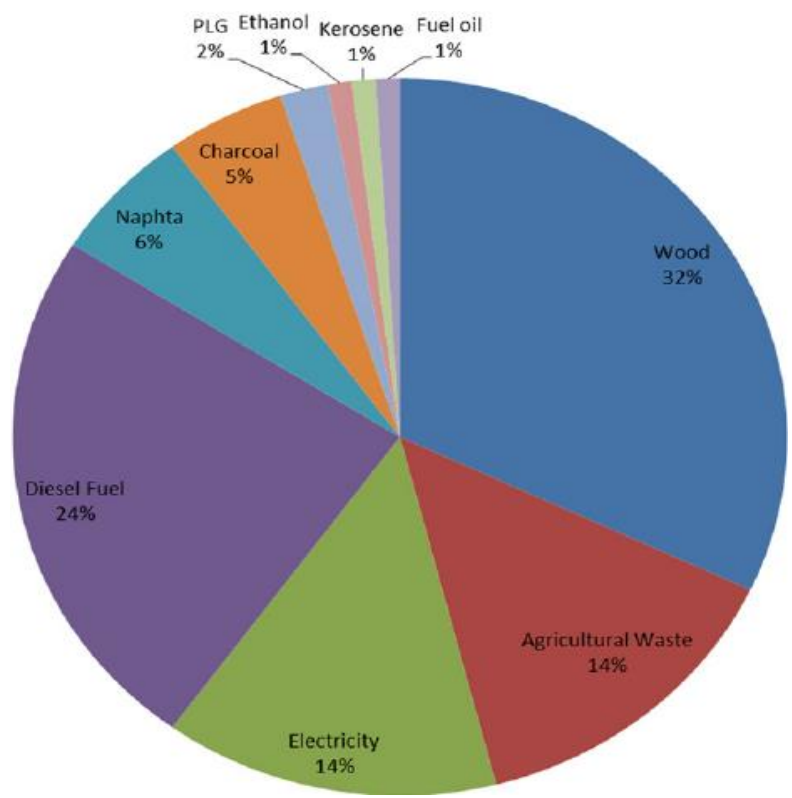

Figure 20. Energy Mix in Paraguay

\subsection{Bolivia}

The fossil fuel dominance is almost total for this poor country, as hydro power is not as large as in several other LA countries (Figure 21). Yet, its natural gas reserves are so large that Bolivia dreams about becoming a major LA exporter of gas or electricity. Can a nationalised industry handle such a major goal? In any case, Bolivia may replace oil with natural gas.

\section{Total energy consumption in Bolivia, by type (2011)}

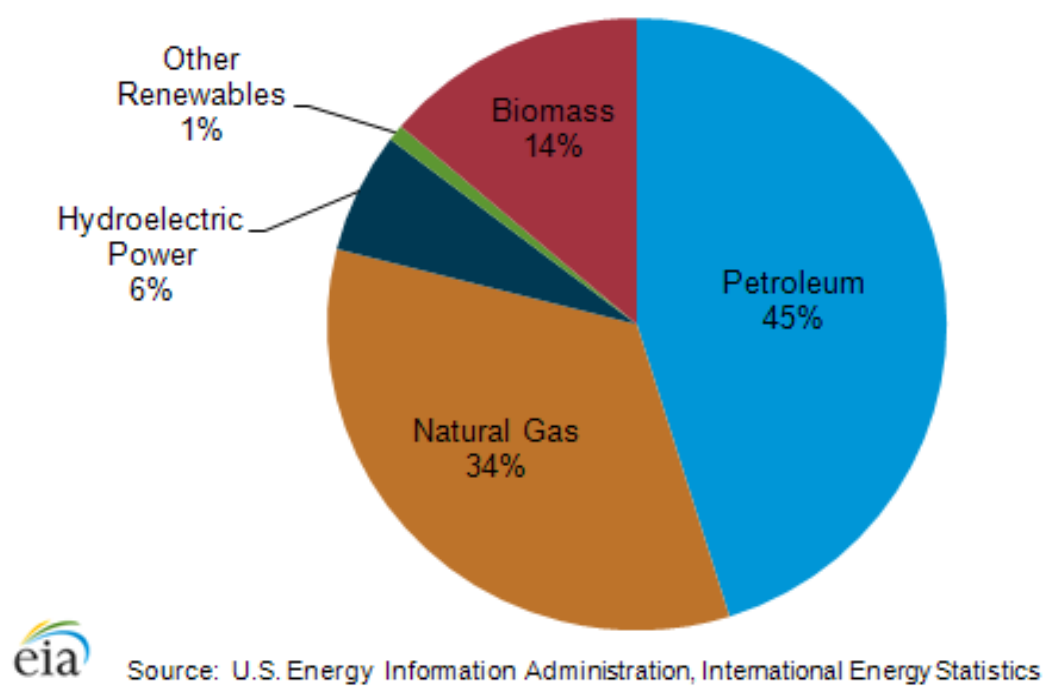

Figure 21. Energy in Bolivia 


\section{Global Warming Policies or Sustainable Development Goals for LA}

Economics is, as T. Carlyle said, a "dismal science", analyzing the IS and not the OUGHT. And the Malthusian predicament is with us with a vengeance in the form of the energy-emissions conundrums. Insisting upon the positive nature of economics, "positive" referring to the understanding and prediction of the IS, one cannot but realize that sustainable development theory deals with the OUGHT. The gulf between normative utopia and harsh reality forces one to look for how adherents of sustainable economics get from realities to vision. Take the example of Sachs, stating about SDG (sustainable development goals):

“... the SDGs need the identification of new critical pathways to sustainability. Moving to a low-carbon energy system, for example, will need an intricate global interplay of research and development, public investments in infrastructure (such as high-voltage direct current transmission grids for long-distance power transmission), private investments in renewable power generation, and new strategies for regulation and urban design".

But Sachs does not inform us how something so "phenomenally complex" is to come about, going from the IS to the OUGHT. He continues:

"Market-based strategies (such as carbon taxation) can help to simplify the policy challenge by steering private decisions in the right direction, but politics, planning, and complex decision making by many stakeholders will be unavoidable".

Source: http://www.thelancet.com

Of course, but what is the likelihood that a carbon tax can be put in place (where, how much) as well as how large is the probability that planning works? Only wishful thinking!

Sachs realizes the gap between desirability and feasibility, but he confronts the gap by almost religious make beliefs. He states:

"The SDGs will therefore need the unprecedented mobilisation of global knowledge operating across many sectors and regions. Governments, international institutions, private business, academia, and civil society will need to work together to identify the critical pathways to success, in ways that combine technical expertise and democratic representation. Global problem-solving networks for sustainable development - in energy, food, urbanisation, climate resilience, and other sectors-will therefore become crucial new institutions in the years ahead".

Source: http://www.thelancet.com

What is at stake for most people who understand the risks with climate change is not the desirability of decarbonisation in some form or another. They crux of the matter is: How to promote decarbonisation so that real life outcomes come about? The COP21 framework, and its three objectives, namely:

a) Halting the increase in carbon emission up to 2020 (Goal I),

b) Reducing CO2:s up until 2030 with 40 per cent (Goal II),

c) Achieve more or less total decarbonisation until 2075 (Goal III),

will prove too demanding for most countries, I dare suggest. What are the real obstacles for any 
decarbonisation project, if we stick to the social sciences as ethically neutral and truthfully objective? The energy-emissions conundrum!

Decarbonisation, resulting from the anthropogenic causes of $\mathrm{CO} 2 \mathrm{~s}$, can only be done when the fundamental pattern of energy consumption is transformed. At the present, energy comes from mainly fossil fuels and wood coal. Energy is the capacity to do work, which implies that energy consumption is a sine qua non for affluence, following Adam Smith and Say among the classics. The Utopians like Sachs promises that economic development will not be compromised, as SDG would include the Millennium Development Goals (MDG):

"The MDGs were targets mainly for poor countries, to which rich countries were to add their solidarity and assistance through finances and technology. The SDGs will, necessarily, have a different feel about them. Sustainable development is eluding the entire planet. The SDGs should therefore pose goals and challenges for all countries - not what the rich should do for the poor, but what all countries together should do for the global well-being of this generation and those to come. Middle income emerging economies, such as Brazil, China, India, and others, will be crucial leaders of the SDGs, and will have their own internal challenges of balancing growth and environmental sustainability; vulnerabilities to adverse trends such as climate change".

Source: http://www.thelancet.com

Compare this message with the cautious policy stance of another global economist with expertise on climate change, N. Stern. In his new book (1916), he argues for a quick policy response to the global warming challenges, admitting that mankind could fail miserably. His suggestions include:

i) "Accelerating the shift away from fossil fuel power generation..."

ii) "Halting the deforestation of natural forests..."

iii) A shared commitment to simultaneously to promote economic development, overcome poverty and manage climate change responsibly..." (Stern, 2016, p. 296).

In light of these three Stern objectives, Latin American is highly relevant and interesting. It depends far too much upon oil and natural gas. It accelerates deforestation in the Amazons, inter alia. And it will never overcome poverty in this century.

Stern is surprisingly vague about his earlier proposal that advanced economies assist catch+up or take+off economies. He now says cautiously:

iv) “...at a minimum, measures to realize the Copenhagen-Cancun promises of flows of $\$ 100$ billion per annum to developing countries by 2020" (Stern, 2016, p. 297).

But this is the gist of the entire COP21 approach! Without this money, countries will renege. But these enormous sums will come from where?

Stern, more of a realist than Sachs, warns us that the next two decades will be decisive in the fight against climate change. That is too short a time for mankind, being around for some 80000 years as Cro Magnons. Too many, global warming is not so serious, just a topic of debate for lots of COP meetings - transaction costs! Men and women are myopic and prefer resilience, meaning acting 
AFTER the catastrophe. Mixing climate change with other human development goals is a sure recipe for coordination failure.

\section{Conclusion}

The COP21 Project has now been formally initiated and LA governments have bound their countries to respect the environmental goals laid down by almost all nations in the world. How prepared are Latin American countries for this required $40 \%$ reduction in their $\mathrm{CO} 2$ :s in 10 years?

Although Latin American only houses two big polluters with carbon dioxide-Mexico and Brazil, the $\mathrm{CO} 2$ :s in all these countries have increased significantly during the last 25 years, following conomic advances. Latin American countries often have other sources of energy than the fossil fuels, like hydro, nuclear and biomass energy, but petroleum and gas play the major role in all except Uruguay. COP21 must therefore be a major challenge for Latin America: How to substitute oil and gasl energy with renewables without loosing the capacity to proceed with economic development and poverty reduction? regions on the globe?!

Latin American countries, or at least some them, are taking their commitments towards COP21 seriously, trying to initiate a movement away from fossil fuels that result in so much CO2:s. The obligation to halt the increase in $\mathrm{CO} 2$ :s has been fulfilled by very few, as of now. But things may change until 2020, when the seminal reduction of $\mathrm{CO} 2$ :s must start in order to comply with promises of a $40 \%$ reduction-quite a number!

Typically, Latin American countries in Meso Ameica as well as South Ameica rely much upon fossil fuels, not coal so much as Asia but petroleum and natural gas. There is a third major power sources in some these countries, namely water, which signicantly adds to the energy mix in Brazil, Paraguay, Uruguay, Chile, Peru, Ecuador, Colombia, Nicarague and Honduras. Cuba on the contrary uses mainly petroleum and natural gas, which also holds for the small islands in the Carribean.

Economic growth in advanced nations or economic development in the Third World has been based upon the burning of fossil fuels, besides the fact that extremely poor countries employ massive amounts of wood coal. And most LA countries, whether it be their governments or their private economies, plan for a sharp increase in energy consumption in the coming decades. Nuclear power is tiny, but solar and wind power is coming strongly. Biomass, biofuels and waste as well as wood are much used as compliments to oil and gas. Look at their energy mixes now and the promise to fulfill COP21 by 2075 with a 95\% carbon free energy consumption-IMPOSSIBLE!

\section{Sources and Literature}

BP Energy Outlook. (2015).

Energy Information Administration (EIA). (2015). Annual Energy Outlook. Retrieved from http://www.eia.gov/forecasts/aeo/index.cfm

EU Joint Research Centre Emission Database for Global Atmospheric Research. (n.d.). Retrieved from Published by SCHOLINK INC. 
http://www.edgar.jrc.ec.europa.eu/overview.php

International Energy Agency (IEA). (2015). World Energy Outlook. Retrieved from http://www.iea.org/bookshop/700-World_Energy_Outlook_2015

OECD National Accounts data files. (n.d.).

Population and Vital Statistics Report (various years), Census reports and other statistical publications from national statistical offices Eurostat: Demographic Statistics. (n.d.).

Secretariat of the Pacific Community: Statistics and Demography Program, U.S.Census Bureau: International Database. (n.d.).

UN Framework Convention on Climate Change. (n.d.). Retrieved from http://www.unfccc.int/ghg_data/ghg_data_unfccc/time_series_annex_i/items/3814.php

United Nations Population Division: World Population Prospects, United Nations Statistical Division. (n.d.).

World Bank national accounts data. (n.d.). Retrieved from http://www.data.worldbank.org

World Resources Institute CAIT Climate Data Explorer. (n.d.). Retrieved from http://www.cait.wri.org

\section{References}

Barro, R. J. (1991). Economic Growth in a Cross Section of Countries. The Quarterly Journal of Economics, 106(2), 407-443. https://doi.org/10.2307/2937943

Barro, R. J., \& Sala-i-Martin, X. X. (1992). Convergence. Journal of Political Economy, 100(2), 223-251. https://doi.org/10.1086/261816

Barro, R. J., \& Sala-i-Martin, X. X. (1995). Economic Growth. McGrow Hill.

Conca, K. (2015). An Unfinished Foundation. Oxford: Oxford U.P. https://doi.org/10.1093/acprof:oso/9780190232856.001.0001

de Bruyn, S. M. (2012). Economic Growth and the Environment: An Empirical Analysis. Berlin: Springer.

Eriksson, C. (2013). Ecofornomic Growth and the Environment: An Introduction to the Theory. Oxford: OUP. https://doi.org/10.1093/acprof:osobl/9780199663897.001.0001

Hayek, F. A. (1991). The Fatal Conceit: The Errors of Socialism. The University of Chicago Press.

Mazmanian, D. A., \& Sabatier, P. A. (1989). Implementation and Public Policy Paperback. Lanham, MD: UPA.

Pressman, J., \& Wildavsky, A. (1973, 1984). Implementation. Berkeley: University of California Press.

Ramesh, J. (2015). Green Signals: Ecology, Growth and Democracy in India. Oxford : Oxford University Press. https://doi.org/10.1093/acprof:oso/9780199457526.001.0001

Rostow, W. W. (1960). The Stages of Economic Growth: A Non-Communist Manifesto. Cambridge: Cambridge University Press.

Sabatier, P. A. (1993). Policy Change and learning: An Advocacy Coalition Approach. Boulder, CO, Westview. 
Sabatier, P. A. (1998). The advocacy coalition framework: Revisions and relevance for Europe. Journal of European Public Policy, 5(1), 98-130. https://doi.org/10.1080/13501768880000051

Sachs, J. (2015). Sustainable economies. Retrieved from http://www.jeffsachs.org/2015/08/sustainable-development-for-humanitys-future/

Sachs, J. (2015, August 10). Sustainable Development for Humanity's Future. Asian Development Bank. Retrieved from http://www.jeffsachs.org/2015/08/sustainable-development-for-humanitys-future/

Sachs, J. D. (2015). The Age of Sustainable Development. New York: Columbia University Press. https://doi.org/10.7312/sach17314

Stern, N. (2007). The Economics of Climate Change. Oxford: OUP. https://doi.org/10.1017/CBO9780511817434

Stern, N. (2016). What are we waiting for? Cambridge, MA: MIT press.

Wildavsky, A. (1978, 1987). Speaking Truth to Power. Transaction Publishers. 